\title{
Author Correction: The therapeutic potential of mesenchymal stem cells in lung cancer: benefits, risks and challenges
}

\section{Lourdes Cortes-Dericks ${ }^{1}$ - Domenico Galetta ${ }^{2}$}

Published online: 11 December 2019

(C) International Society for Cellular Oncology 2019

\section{Author Correction: Cell Oncol.}

https://doi.org/10.1007/s13402-019-00459-7

The author, Domenico Galetta, wishes to update his 2nd affiliation to: Division of Thoracic Surgery, European Institute of Oncology, IRCCS, Milan Italy.

Publisher's note Springer Nature remains neutral with regard to jurisdictional claims in published maps and institutional affiliations.

The online version of the original article can be found at https://oi.org/ 10.1007/s13402-019-00459-7

Lourdes Cortes-Dericks

cortes-dericks@gmx.de; 1cortes@physnet.uni-hamburg.de

Domenico Galetta

domenico.galetta@ieo.it

1 Department of Biology, University of Hamburg, Hamburg, Germany

2 Division of Thoracic Surgery, European Institute of Oncology, IRCCS, Milan, Italy 